\section{THE MYTHICAL ZOOLOGY OF THE FAR EAST}

A SHORT time ago the British Museum acquired a comprehensive collection of Japanese and Chinese pictures, made by Mr. William Anderson, for some years medical officer to the British Legation in Tokio. This gentleman's magnificent work on the "Pictorial Arts of Japan" has already been noticed in these columns; and he has just placed students of the arts of the Far East under an additional debt of gratitude to him by the preparation of a catalogue of his collection in the British Museum, which has just been published by the Trustees of that institution. With this volume, except for a special purpose, we have nothing to do; but it is impossible to glance through it without being struck by the amount of labour which the author has devoted to his dissertations on the various schools of painting, to his descriptions of characteristic examples of these schools, and to his explanation of the motives which inspired the artists. The word "catalogue" is a modest one to employ in describing the work, for though it contains the numbers and names of the pictures, this is the least part of its contents.

Amongst the motives of the artists of China and Japan, mythical zoology held a very important place ; it evidences, says Mr. Anderson, "a courage of invention almost unparalleled in the pseudo-science of Oriental races." It holds, too, a disproportionate place in the folk-lore and superstitions of the people of both countries. Yet it has scarcely received any attention in Europe. In Prof. Angelo de Gubernatis's great work on "Zoological Mythology" there is but a single reference to China, and none at all to Japan, while the myths of Aryan nations occupy the greater part of his volumes. Here and there in books relating to the countries of Eastern Asia scanty references to popular myths respecting animals are found, but, so far as we are aware, Mr. Anderson's is the first work which gives any adequate conception of the marvellous extent of this species of lore amongst the Chinese and Japanese. As the latter owe their art, literature, and religion to China, so they owe also their scientific myths. The Chinese have developed mythical zoology to a greater extent than any other nation. "Their literature teems with strange conceits, some of which appear to be transcripts of local folk-lore, others appertain to Buddhism or Taoistic legends, and others are accepted as sober facts of natural history." These have almost all been adopted and improved in treatment by the Japanese.

Mr. Apderson divides the anthropological myths into three classes:-

(I) Persons born of woman with or without divine agency, who develop magical powers, work miracles, and attain a fabulous longevity.

(2) Those distinguished by physical peculiarities of a fabulous nature. Amongst these are giants ; dwarfs ; perforated men, who are conveyed about by coolies by means of poles put through holes which conveniently exist in their bodies for this purpose; stomachless men, who, according to popular belief, "dare not laugh for they have no sides to hold"; men with enormously long legs, and those with similarly long arms; men with tails, who carefully dig holes where they sit in order to provide a receptacle for the appendage; and many other extraordinary beings, all of which are truthfully described, from Chinese works of authority and repute, in the great Japanese encyclopædia $W a-K a n-S a n-S a i$ dzu-yé.

(3) Transitional beings, who combine with human elements parts naturally appertaining to the lower animals : such are feathered men; those with human faces, but the wings and beak of a bird; mermen, who have human heads and arms attached to the body of a fish, and learn the secrets of the deep from the murmuring hollow of the Conchifer. To this section also belongs the vampire bride who lures men to her deadly embraces till she has drained away their life-blood.

Mÿthical animals are similarly classified :-

(I) Those without any remarkable peculiarities of conformation, but gifted with supernatural attributes. Thus the tiger is classed in Chinese mythology as one of the supernatural animals, the king of beasts, and the representative of the masculine or active principle of Nature. It attains the age of a thousand years, and after passing the half of this term its hair becomes white. It is sometimes seen in association with the dragon, apparently as the emblem of the power of faith ; it is also regarded as the type of wisdom, and in illustration of this attribute Mr. Anderson gives a story (p. 5I) which has a familiar analogy in European folk-lore. The fox, again, is the demon of mischief, with the power of changing his shape at will, but ever with some evil design on the comfort of mankind. When he reaches the age of fifty, Mr. Anderson tells us, he is able to accomplish at will his most favourite and baneful metamorphosis into the resemblance of womankind; at a hundred he can take the shape either of a young and beautiful girl, or of a wizard strong in: all the powers of magic; and when he reaches the term of a thousand years he becomes a Celestial Fox, characterised by a golden colour and nine tails, and may be admitted to heaven. But it appears he does not always avail himself of this privilege, for the possession of the extra tails only gives him an augmented cunning and capacity for wickedness. The tortoise also attains a marvellous longevity, and is variously represented as the embodiment of a star in Ursa Major, and as a descendant of the first dragon. In Hindoo mythology the tortoise supports the elephant which supports the world ; in Japanese art it is represented as bearing on its back the mountain abode of the immortals. The horse is also associated with longevity, and it is still a popular belief that the female is delivered of its progeny through the mouth. The crane is one of the commonest figures in Japanese art; in Chinese mythical zoology there are four varieties, distinguished by their colours; they all live to a fabulous age, and after completing six hundred years are superior to the necessity of other sustenance than water. Many other notices of animals belonging to this class are scattered throughout Mr. Anderson's book in connection with pictures in which they are represented.

(2) Animals differing from their fellows only in size, or in alterations of the due number of parts. Such are serpents eight hundred feet long, which devour elephants; nine-tailed foxes; the four-eared monkey which heralds the deluge; the fish with ten bodies and one head, whose flesh is a sure preventive of boils ; and many others.

(3) Creatures made up by the amalgamation of parts of various animals. Amongst these composite monsters the principal is the dragon, which, according to the: Japanese encyclopædia already mentioned, has the head of a camel, the horns of a deer, the eyes of a demon, the ears of an ox, the body of a serpent, the scales of a carp, and the claws of an eagle. It is not necessary ta say more by way of description, for it is the most familiar object in the art of China and Japan. It is treated by writers of the last century as really existing. It becomes at will, according to a Chinese author of the seventh century B.C., reduced to the size of a silkworm, or swollen till it fills the space of heaven and earth. "In Chinese Buddhism it plays an important part, either as a force auxiliary to the law, or as a malevolent creature to be converted or quelled." It is a guardian of the faith, an attribute of saintly or divine personages, an enemy of mankind, an emblem of majesty, the presiding genius of rainfall, and a symbol of time and place, giving its name to certain days and years, and to a point of the compass. Many more details about this extraordinary creature will be found scattered through Mr. Anderson's book, especially on pp. 48 et seq. The kilin or kirin, "the noblest form of the animal creation, 
and an emblem of perfect good," also belongs to this class. It has the body of a deer, the tail of an ox, and a single horn, so that it resembles the unicorn. The phœnix is another animal of this kind, with the head of a pheasant, the beak of a swallow, the neck of a tortoise, and the outward resemblance of a dragon. It is regarded as an omen of good, and heralds the advent of a beneficent reign. "In works of art it is a nondescript bird of gorgeous plumage, intermediate between that of the peacock and bird of paradise, and bears flame-like appendages where the neck joins the body."

All the creatures referred to here, and many more belonging to one or other of the classes of zoological myths, are represented pictorially in the Wa-Kan-SanSai dzu-yé, already mentioned, and in the Mangwa of Hokusai, a book to which access can be obtained without difficulty in most of the capitals of Europe.

To the mythical animals already mentioned, which are common to China and Japan, the Japanese have added some of their own invention. Such are serpents, giant centipedes, monster devil-fishes ; earth-spiders, probably representing the troglodytes of old Japan; the raccoon-faced dog, which possesses in a minor degree the evil powers and tendencies of the fox; the wolf-like animal which produces thunder; the "whirling neck," or being which has the power of so elongating the neck that the head appears in places remote from the body ; the mandevouring $k a p p a$, which frequents rivers and ponds, and politely challenges wayfarers to single combat ; and many other.equally strange creatures. An outline sketch of Japanese demonology will be found at p. 59, and a striking myth of a demon spider at p. 109.

Enough, however, has been said to show that if $\mathrm{Mr}$. Anderson, in his catalogue and larger work on the "Pictoral Arts of Japan," has revealed to British readers a new and most important branch of art, he has incidentally indicated to his readers a new world of myth, which has hitherto found no place in the consideration of students of comparative mythology in Europe, but which can now be no longer neglected. Mr. Anderson of course treats it almost solely in its relation to art, but he informs the reader in every case where further and more detailed information may be obtained. The task of tracing these myths to their source and of finding analogies elsewhere is one for the scientific inquirer. Mr. Anderson has done the more laborious part of the work in bringing them together. He also suggests that very many of them will be found to have their homes in India, and to have spread with the doctrines of Buddha to China and other far eastern countries. One great advantage which the student of the zoological and other myths of China and Japan will have is that in the exhibition of the Anderson Collection, which is shortly to be opened at the British Museum, he will be able to see in the most graphic form the conceptions of successive generations of artists of the beings to which the myths relate--an advantage which could not be obtained even in the countries themselves without considerable expenditure of money, time, and labour. It only remains to be said that we have adopted Mr. Anderson's classifications, and in many instances have employed his own words in the descriptions of the myths scattered in so much profusion throughout the catalogue.

\section{NOTES}

We regret to have to announce the death, on Good Friday, at the Nice Observatory, of M. Thollon, the eminent spectroscopist. Few men devoted to spectroscopic inquiry have worked so unceasingly and successfully; and in him Science loses one of the most single-minded of her votaries. He has been cut off in the midst of his labours, which, especially since his loca- tion at M. Bischoffsheim's magnificent obiervatory and the completion of the spectroscopic installation there, have borne such rich fruit in the shape of a method of sorting out the telluric from the true solar lines (a method slightly modified by Cornu), and of a map of the solar spectrum as observed by the new form of spectroscope of his own invention, which vastly surpasses in dispersion and purity of image anything that preceded it. Dr. Thollon has not only worked at Nice, but at the Pic du Midi and the Paris Observatory; he was also one of the observers of the total solar eclipse in Egypt in 1882 . In all his wanderings, as in his work, he made many friends, and all who knew him will mourn his loss, not only as a man of science, but as one possessing, above the ordinary degree, a true and genial nature.

ON March 5 a drawing-room meeting for the promotion of technical education was held at the house of Mr. E. C. Robins, under the presidency of Prof. Huxley. A Memorandum of the proceedings has now been printed for private circulation. An address on the technical training at the Central Institution at South Kensington was delivered by Prof. Ayrton. The address was followed by a discussion, in which Prof. Silvanus Thompson, Mr. Brewin, Prof. Perry, Prof. Henrici, and others took part. In summing up the debate, Prof. Huxley remarked that something had been said about rivalry between the Central Institution and the Finsbury School. That most excellent and vigorous school which the City and Guilds Institute had established at Finsbury was chiefly intended to give primary technical instruction to workmen and others who could snatch only a few hours a week from their daily labour for the purpose of receiving it. The Central Institution, on the other hand, was chiefly intended for the advanced instruction of persons who could give up their time for one or more years to the higher branches of technology. Exhibitions enabled the promising student of the schools at Finsbury and elsewhere to pass to the Central Institution, and profit by the advantages it offered him. To talk of rivalry between the two was like talking of a rivalry between Eton and Cambridge. No doubt the day would come when a score of such schools as that at Finsbury would be sending their picked scholars to the Central Institution; but, before that day could come, the organisation of the Central Institute must be so far completed that it could receive them and deal with them. A great deal had been said about the $100,000 l$. or $150,000 l$, or whatever it was, that had already been spent on the Central Institution, and of the ro,ool. a year that it cost. He begged leave to repeat that which he had said elsewhere, that if in the course of the next ten years the City and Guilds Institute could succeed in catching and training another Faraday or Whitworth or Armstrong, he would from a mere commercial point of view be worth all the expenditure initial and assured.

A HIGHLY interesting series of experiments has recently been successfully carried out by $M$. Olszewski. The more permanent gases have not only been liquefied at pressures averaging only $740 \mathrm{~mm}$. by aid of excessively low temperatures, but the boiling-points, melting-points, and densities of these so-called gases have been determined at atmospheric pressure. The glass tube in which the condensation was effected was surrounded by a bath of liquefied ethylene, which could be caused to boil by reduction of its pressure, and, by use of a specially constructed air-pump, was reduced in temperature to $-150^{\circ}$. When this point was reached, the gas to be liquefied was admitted into the tube from a Natterer cylinder containing the gas at about 40-60 atmospheres pressure, and was readily liquefied. A hydrogen thermometer was used to determine the temperature of the liquid, and the boiling-point of methane at 